\title{
In Search of an Effective Model for Assessing Learning in Bilingual Education: the Authentic Assessment
}

\author{
JuAN A. Martínez LÓPEZ \\ Víctor CANTERo García \\ Universidad Pablo Olavide, Sevilla
}

Received: 12 June 2012 / Accepted: 29 May 2013

ISSN: 1697-7467

\begin{abstract}
We have a commitment to provide the most efficient, transparent and coherent evaluation procedures for bilingual education. In this articlethe authors offer all teachers of bilingual education a theoretical as well as practical approach to the so-called authentic assessment. Our aimisto provehow this method can be usedas an alternative to the traditional methods of evaluating the learning-outcomes of linguistic content by the students in our bilingual sections. This alternative requires a substantial change of focus for the teachinglearning process, since evaluating is not equivalent to examining when it comes to quantify results, but rather valuing the capacity of the student to solve competently the problems they meet in real life.Our proposal is meant to be applied in the classroom environment, thus the second part of our work applies authentic assessmentto a $4^{\text {th }}$ grade Social Science didactic unit in a bilingual secondary school in Spain, $\left(4^{\circ} \mathrm{ESO}\right)$. This practical example may be used as a pattern for new experiences through which teachers can personalize their evaluation strategies and achieve a more authentic assessment of students' learning.
\end{abstract}

Keywords: bilingual education, authentic assessment, learning of linguistic contents.

En busca de un modelo eficaz para evaluar los aprendizajes en la educación bilingüe: la evaluación auténtica

RESUMEN: Asumido el reto de dotar a la educación bilingüe de un sistema evaluativo eficaz, transparente y coherente, en este artículo se ofrece a los docentes de las aulas bilingües un acercamiento teórico-práctico a la denominada evaluación auténtica. El objetivo de la presente colaboración consiste en demostrar la viabilidad de un sistema alternativo al tradicional a la hora de evaluar los aprendizajes lingüísticos de los alumnos que cursan sus estudios en nuestras Secciones Bilingües. Dicha alternativa demanda un cambio sustancial en el enfoque el proceso de enseñanza-aprendizaje, pues ya evaluar no equivale a examinar para cuantificar resultados, sino a valorar la capacidad del alumno para resolver con soltura aquellos problemas que se presentan en la vida real. Con el fin de que nuestra propuesta descienda a la realidad del aula, la segunda parte de nuestra aportación consiste en la aplicación de la metodología de la evaluación auténtica a una secuencia didáctica del área de Ciencias Sociales para $4^{\circ}$ de ESO bilingüe. Esta ejemplificación puede servir de pauta para nuevas experiencias, a través de las cuales los profesores personalicen sus estrategias de evaluación. Todo ello en pro de lograr modelos más auténticos y fiables a la hora de valorar lo que nuestros alumnos aprenden.

Palabras clave: educación bilingüe, evaluación auténtica, aprendizaje de lenguas. 


\section{INTRODUCCIÓN}

One of the repeated concerns by those who in recent years have worked in the bilingual classroom, is how to achieve an evaluation model for language learning according to the characteristics of bilingual education. This has been particularly important for us since the academic year 2005-2006, when the Plan de Fomento del Plurilingüismo de Andalucia was approved. Both in the area of University teaching, as well as through practice in the bilingual classroom at secondary school, we understand that the option that best responds to our demands is the so-called authentic assessment. On reflecting about what could be the most successful method for evaluating what our students learn in classes where the content is taught in a second language (L2), emerges our interest in demonstrating the advantages that authentic assessment reports to bilingual education: being the evaluative model that best fits an objective assessment of language learning of our students.

We started our contribution exposing those methodological and pedagogical principles of bilingual education that, in our view, are demanding an evaluation procedure of the teachinglearning process quite different from the conventional. It is often claimed that in bilingual education, the L2 becomes an instrument for learning, turning it into a resource vehicle for the assimilation of contents related to real life. This is an approach to learning that demands evaluation through authentic tasks resolution; that is, similar to those that students find in their daily lives. This view is sustained by the Plan de Fomento de Plurilingüismo de Andalucia, in which we find phrases such as "learning a language involves the development of linguistic, textual, discursive and cultural skills, giving languages the nature of cultural vehicle par excellence" (Ministry of Education, 2005:10).

Once proven that already from the very essence of bilingual education there is a claim for a specific model for the evaluation of learning, we arrive at authentic assessmentas the ideal alternative. A new way of evaluating, defined by Wiggins (1993:229) as: "the procedure whereby the students have to solve authentic problems, relevant, because of its importance, for whose resolution they must use knowledge in order to achieve effective and creative responses.Therefore the tasks must be a replica, or be similar to the kinds of problems faced by adult citizens, consumers or professionals in each specialty."A definition reinforcing the reasons for our choice, when contrasted with the pretensions of traditional evaluation, as in Álvarez Valdivia (2005:50):

No se orienta hacia un aprendizaje para la vida, hacia un aprender para ser más eficaz en el desempeño de tareas cotidianas, hacia aprender para ser autosuficiente, sino que se queda en la valoración sumativa de lo aprendido por el alumno, sin tener presente su aplicación en la vida practica del aprendiz.

We start from a conception of education understood as a process of acquisition by the subject of those competencies that are essential to confront successfully the tasks of daily life. And when we talk about competencies, we address a system of complex actions that cover the knowledge, skills and attitudes required to carry out the tasks successfully. i.e., we refer to a set of variables that, in the words of Wolf (1993:234): "have to be assessed through authentic tasks, since the more authentic the evaluation activities are, the more similar they are to the form as students routinely use the foreign language, thus it is easier to make inferences about the performances of these students". This new concept of educa- 
tion requires a new paradigm of verification of learning, a new way to assess the capacity of our bilingual students to apply their mastery of the L2 in the resolution of specific tasks, and this new way of weighing up learning is what we call authentic assessment. Through this way of assessment we do not intend to measure knowledge acquisition out-of-context, but we trust the students' ability to construct their own learning of the L2 in a natural way. Thus understood, the evaluation becomes an indicator, to a certain extent that the teacher may use to check to what extent the students are able to develop their learning on the basis of their previous experiences and correcting possible mistakes. Ultimately, we are practicing self-learning, which brings about a new approach for the study of languages previously point to by Lorenzo et al. (2009:22): "in recent timesthe study of languages is a progressive abandonment of structural teaching methods to move to more inclusive and communicative ways of understanding learning in a context of use of the language."

We proceed to make the leap from theory to practice, adopting authentic assessment methodology as a learning assessment procedure in a didactic sequence for a 4th grade of bilingual social science class of students in a Spanish secondary school. This is a choice that allows us to transform the evaluation in a tool modifier of the learning-outcomes, a resource that is not a prioriby the school curriculum. The evaluation is turned into an instrument that helps students to resolve the difficulties they face, and motivates them to continue learning. A way of transforming the assessment into authentic assessment, according to MacDonald (1992: 159): "the students must perform a series of tasks to demonstrate their skills, a demonstration that will boost the development of the curriculum, which must be capable of enabling students to take these tasks successfully and that they acquire the essential knowledge and skills." Through this example we credit our change from traditional or summative assessment and make clear we need evaluative approach criteria. This approach is materialized in the delimitation of minimum objectives or standards, establishing the criterion that measures the degree of success of the executed tasks, and in the elaboration of the rubrics or scoring scales. This is a question of how to achieve a reliable instrument of evaluation, suitableto check to what extent the bilingual students perform better than their monolingual peers, a statement first formulated by Cummins (1978: 130), who proved that bilingual students score better than monolinguals in various tests (i.e. verbal intelligence, conceptual training, global reasoning, discovery of underlying rules, troubleshooting), as well as tasks involving reflection on it.

We finish our exposition with a series of conclusions of our adoption of authentic assessment as a filter of evaluation for reliable measurements of the levels of learning of our bilingual students. We want to put on record that mastery of a foreign language gives the learner the ability of solving new problems and learn new realities, a capacity that must be valued, self-fulfilling and enhanced from the early childhood education up to university studies.

\section{WHY DID WE USE AUTHENTIC ASSESSMENT TO MEASURE LEARNING OF BI- LINGUAL PUPILS?}

The first reason for our choice can be found in the recommendations of the Common European Framework of Reference for Languages (CEFRL): teaching, learning and assessment (2001:187), in the section dedicated to the evaluation of language learning, it states 
that measuring the L2 learner's degree of linguistic mastery involves measuring and assessing competencies, indirectly measured through actions. And assess mastery of a language through its use in the performance of real-life tasks, this is precisely authentic assessment. As Lorenzo et al. (2004: 261) pointed out, linguistic mastery "no puede ser únicamente evaluado mediante pruebas de nivel, sino que precisa de un modelo de evaluación que no puede ser una actividad puntual al final de un periodo de aprendizaje, sino que deber estar integrado en el proceso de aprendizaje". The model is not only used to verify the successes and mistakes of the students, on the contrary, it has to push them towards success. As pointed out by Antúnez (1997: 125), "la finalidad de la evaluación es mejorar la interacción pedagógica, integrando todos los elementos que intervienen en los programas, para adecuarla cada vez más a los alumnos y comprobar si estas interacciones han sido eficaces o no".

And if we are looking for an effective way to evaluate the progress of the pupil of the bilingual classroom, we opt for one we believe values its discursive practices best, and this is no other than authentic assessment. It can perceive the ability of the student to deploy all discursive elements required in accomplishing certain tasks, which carry the nickname authentic, yet, according to Coelho (2004:261), among the proposals to formulate a correctprocess of appropriation of a new language has been: "diseñar tareas de evaluación basadas en actuaciones realistas de aplicación de los conocimientos y de las destrezas adquiridas, distribuir en una rúbrica los diferentes niveles de logro en aspectos específicos de la actuación y mostrar ejemplos de los diferentes resultados de la tarea."Actions that simulate situations in the everyday life of the student, and that in the view of Brown (2004:13), is what differentiates the mechanism for the collection of data from alternative assessment models such as authentic assessment, "la cual es una evaluación continua, vinculada a tareas comunicativas, contextualizadas, que tiene como referencia unos criterios de actuación y valoración; que es formativa, pues se centra en el proceso de aprendizaje y promociona la motivación intrínseca". We refer to actions that take shape in oral and written tasks, all of them related to the learning objectives. "Tasks which are assessed according to criteria that help teachers to select the points that should be noted in each case, which will be punctuated as determined in the corresponding matrix, rubric or curve of double entry, describing criteria and quality standards of a certain task, goal or general competence of high complexity", Pellicer and Ortega (2009:95). We refer to an evaluative approach of direct observation of the discursive practices of the apprentice, the CEFRL model itself already describes (2001:178-179) authentic as, every time "that the evaluation of language learning requires verification through the practice of a number of significant and relevant speeches".

A second argument we believe sustains the union between bilingual education and authentic assessment, is the focus on natural second language learning in the bilingual classroom. i.e., the linguistic learning in bilingual education needs to be developed through language exercises that bring language-acquisition in natural environments closer to the student, as well as closer to the pupil's real life. A logical consequence of this learning proposal must be evaluated by procedures inspired by the everyday practice of the language, which is the case of authentic assessment. But to make this link between the natural method of learning the L2 and its corresponding assessment effective requires the full involvement of the teacher, who needs a specific professional competence, and a special ability to create curricular content through language learning situations. We refer to a teacher with expertise in fostering interpersonal relationships and in creating a communicative environment that motivates a natural 
and spontaneous L2 learning in the classroom. This is highlighted by Tudor (2001:43): "the teaching of languages is a complex activity (...) and the classroom is the place in which they are and interact with a variety of potentially different participants."

The authentic assessment, is by its very nature, an inseparable part of the teachinglearning process, as Black (1998:24) put it: "in the authentic model of assessment, the act of assessment does not separate the teaching-learning process; evaluation is planned and takes place at the same time that as the student is taught". This is the third reason behind our choice; the dynamics of authentic assessment does not exclude any of the protagonists of the educational act. On the contrary, the teacher and the student both experience a continued review of their roles and a permanent feedback from learning. The successes and the mistakes of students while they carry out their tasks, serve to make the teacher review his or her practical teaching, to take note of the areas for improvement in their methodological strategies, to look for alternative proposals so that the students can achieve a better understand of the material being explained. These suggestions demonstrate that the teacher is no longer the protagonist of the learning of their students, but rather the promoter of them. This is the profile of the teacher demanded in bilingual education, because as Barberà (1999:193) says, in the bilingual classroom: "the student is not the sole purpose of the valuation, because learning is not only and exclusively the student's responsibility, but is the result of the interaction of many factors. The regulation of the educational process is not limited to learning, but extends its borders, so it is reasonable to think that the teaching is also capable of evaluation." However, once said it is important that the teacher should make the required modifications in the evaluation through the way he or she teaches content through the L2, it is not less important that students learn from their mistakes. This is the formative value of authentic assessment, which fosters the intrinsic motivation of the language learner, transforms it into regulator of their own learning, helps you to maintain an attitude of lifelong learning, ultimately elevates it to the category of protagonist of a social phenomenon called bilingualism, which, in the words of Sánchez and Tembleque (1986): "as a linguistic phenomenon, it is not an isolated element, but that it is framed within a specific social, political and economic situation."

The fourth and last of our arguments, is based on the recommendations from various official reports on the bilingual programs in our educational system. In all of them the need for a model of evaluation for this education is emphasized, such is the case of the report entitled Programme of bilingual education in Spain: evaluation report, MEC-British Council, in which Dobson et al. (2010:159), state the need for: "a model for the evaluation of bilingual education that is in the service of learning, an assessment measure yields based on the degree of exposure of students to English and concrete in realization of tasks". And this is just what was intended with the implementation of the authentic assessment, which should serve to measure the progress of pupils in the mastery of the L2. This new method of evaluation of language learning was commented in the report: Bilingualism and education: situation of the network of bilingual schools in Andalusia. In the conclusion, Lorenzo et al. (2009:23) require that: "the teaching of foreign language in bilingual programs also shows positive results in a short period of time, presenting a considerable increase in the rhythms of acquisition of L2."

The underlying idea is that bilingual education promotes a new approach in relation to the learning of languages, something which is reflected in Duvenger and Maillard (1996:240): 
The teaching and the study of a foreign or second language involves a series of cognitive advantages, through reflection on the linguistic and communicative functioning of the non-mother tongue, the student creates an instrument that facilitates and regulates learning this language but, in turn, by contrast improves also the use of the mother tongue.

This approach demands an alternative procedure to assess such learning, which is described as authentic by Gulikers et al. (2005:516), "pues lo que hace de verdad auténtica a la evaluación es que esté basada en la medición de la capacidad del alumno para realizar tareas reales, como elemento base para desarrollar sus competencias."

\section{Approaching the Signs of IDEntity of The "Authentic ASSESSMent"}

Although we have already pointed at some of the advantages of the application of authentic assessmentin the evaluation of language learning in bilingual education, we believe it is necessary to show the reader both the origins and the constituent elements, as well as the dynamics of this evaluation procedure. The traditional system of evaluation, such as measurement of results and numerical comparison of them, appears in 1973 understood as assessment or valuation assessment. A conceptual shift Worthen and Sanders (1973:98) referred to when identifying evaluation as: "the determination of a value, which means obtaining reports to judge the value of a program, a product, a process or objective or the potential usefulness of alternative approaches to achieve specific goals." However, this assessment provides us with verifiable data, valid and contrastable with regard to the students' levels of learning needed. These learning-outcomes are demonstrated by the student through the application of their knowledge and skills in solving real problems. Here lies the substantial core of the "authentic assessment", conceived as such by Mueller in its Authentic Assessment Toolbox and in the eighties of the last century it was adopted as an evaluation procedure in the United States. As added by Mueller (2005:14), the authentic assessment movement then reached Europe, and spread over the rest of the world. We are talking about an evaluation method that focuses on empirical demonstration of the success by the student with regard to the implementation of their ability to solve real problems by means of acquired learning, an approach in which: "students are asked to perform real-world tasks to demonstrate meaningful application of essential knowledge and skills".

This definition of the act of assessment carries a profound change in the practice of evaluation in the school environment. Now, we are not only interested in checking the curricular contents that our students know, but want to see what they do with what they have learned. This is the reason why we call it authentic, as it requires the student to demonstrate a practical and hands-on demonstration of what he or she knows, turning it into "learning by doing". This new perspective is the difference between the conventional model of evaluation and the authentic, because as Stiggins said (1987:34), the authentic: "is to show the specific skills, specific competences of the student to successfully resolve what is asked."

We move on to a description of the distinguishing features that separate authentic assessment as an alternative method for the measurement of learning. The first distinctive feature of this new form of evaluating consists of giving priority to the development of authentic 
and verifiable learning in our classrooms. Honesty and transparency are fundamental features, because the students should learn and be evaluated within the same paradigm. What is demanded in bilingual education is this setting between learning focused on authentic tasks and assessment of lessons learned from practice. This, in other words, means that in bilingual classrooms, what must be assessed is the real capacity of the student to use the linguistic and communicative contexts of the L2 in their daily lives. According to Stein et al. (2004:244)the authentic assessment learning demands that the proposals must be transferable to the real world. The point is to situate the students in front of real learning situations to make them decide what they must learn, involving the promotion of intrinsic learning, which is the students themselves who regulate what they learn, it is them who build their learning process based on the resolution of authentic tasks.

If the learning-outcomes are authentic, the tasks that are developed and applied must also be so. This is the second feature of the assessment model that we are describing. When we talk about authentic tasks, we refer to tasks which are characterized by the necessary and specific operations to achieve the expected results, to develop the criteria of assessment based on the articulation of those tasks. This clear linkage of tasks with learning processes means thatevaluating and learning are two sides of the same coin, because, as Gulikers, Bastiaens and Kirschner (2004:68) indicated: "both influence strongly the one into the other. To change the learning-outcomes of students in the direction of the development of authentic competencies, teaching should be authentic and competency-based, aligned also with an authentic, competency-based assessment." That is, if we change how to evaluate what our students learn, we will also have the possibility of changing the model through which we teach what we want the students to learn.

The third pillar of this new form of evaluation is the formative character, namely: the granting to the learner new opportunities to amend his mistakes and learn from them. The act of evaluation is not to punish the acquired learning, but facilitating the achievement of meaningful, critical and reflective learning of the content object of study, a feedback process for the student, thanks to which, the new learning comes to enrich and consolidate the previously acquired knowledge and in which the teacher plays a crucial role. As a consequence, the formative value of the authentic assessment will benefit the teacher and the pupil in equal parts, because as pointed out by Lopez (2008:13): "the teacher gets the information he or she needs to make decisions, in relation to how to improve in the process of teaching and learning, while the student knows the precise situation of learning that is where he walks and what he needs to do to reach the goal." Ultimately, both take advantage of the formative evaluation of nature, as evidenced by the following the comments of Gips (1994:124): "formative assessment involves using assessment information to feedback into the teaching/ learning process, some emphasized that assessment is only truly formative if it involves the pupil, others that it can be a process which involves the teacher who feedback into curriculum planning". A mutual use of Marchese (1991:5) arises from the fact that evaluation: "is designed to guide both instructors and students by providing insight on student learning and the effectiveness of instructional activities."

However, this new form of evaluation that in the words of Margalef (2009:110), "requires the transformation of beliefs and attitudes towards the process for designing and implementing evaluative practices consistent with a learning-oriented education", works according to its own principles. The process begins with a basic question: What should students 
know and be able to do? The response to the same arises standards or general purposes, the general objectives which, in the opinion of teacher should be achieved by the pupils. These "standards" are divided into: the content standards: as statements that describe what students should know, or be able to do, with the content of a specific discipline, or at the interaction of two or more disciplines; the standards process: as statements that describe skills students should develop to enhance the process of learning; and the value standards: statements that describe attitudes teachers would like students to develop toward learning. As soon as the basic objectives are established, we should identify the tasks to achieve the objectives. In order to do this, we ask the following question: What indicates students have met these standards? To determine whether the students have met these standards, you design or select the relevant authentic task. However, to measure the degree of success in the realization of the tasks, we need a set of criteria. This leads us to the next question: What does good performance on this task look like? To be able to evaluate to what degree the students have performed well on the task, you will identify and look for characteristics of a good performance: the criteria. When we apply the criteria we try to translate the levels of success in the implementation of the task by means of a measuring instrument. To do so, we have rubrics. A rubric is a scoring scale used to evaluate students work. A rubric is composed of at least two criteria by which students' work is to be judged on a particular task, and at least two levels of performance for each criterion.

These four steps make up authentic assessment, an evaluative model which, according to Chickering and Gamson (1987:4), aims to: «promote good teaching-practices, through which students can learn significantly in contact with real and active environments close to the reality of the street."

\section{Implementing the PROPOSAls OF THE AUTHENTiC ASSESSMENT TO A DIDACTIC SEQUENCE FOR BILINGUAL EDUCATION}

Appling the tenets of the authentic assessment to bilingual education have supposed that we assume a substantial change in the evaluation procedure. This change focuses on understanding the evaluation as a process strongly linked to the nature of learning. As Ahumada (2005:15) put it: it is "completely inherent in all learning, as an inherent model to the regular development of various activities or learning situations, generated by the teacher in the classroom". To exemplify this change, we have prepared a proposal of evaluation based on bilingual students performing authentic tasks for a didactic sequence in the Social Sciences area for 4th grade of ESO in a Spanish Secondary School.

\subsection{General proposal of a didactic sequence for bilingual education}

\subsubsection{Profile of the sequence}

Title: WWII: History and society

Linguistic level according to the CEFRL: A 2.1

Language: English 


\section{Subject: Social Sciences}

Curricular correspondence: $4^{\circ} \mathrm{ESO}$

Time: 5 sessions

Thematic core: Political, social and economic events during WWII

Thematic script:The didactic sequence focuses on presenting the most outstanding aspects of the Second World War to the student. We put students in contact with the war facts, political tensions, the ideological struggles and the social and economic consequences of the war.

Core competencies to be developed:Linguistic and communicative competence through speaking and writing in L2 (English) as vehicular language for learning content.

Practical observations:The contents of the sessions may exceed the time that each class lasts so activities not completed in the current session, continue to the next.

\subsubsection{Outline of the sequence:}

General objectives:

- To know the political, social and economic factors that brought about the Second World War.

- To understand the consequences of the war: the Division of Europe into blocks.

- To locate properly in space and in time the war events.

Curriculum:

- The causes which led to the start of the war.

- Graphic representation of temporal and spatial sequences that make up the conflict.

- The ways of organizing the economy, society and politics on each side.

- The ideology-propaganda pairing: the imposition of power by force.

Linguistic objectives:

- Demonstrate effective communication skills correctly using the L2 oral presentations.

- Be able to describe in detail, using the L2, the events that mark the contest.

- Showfluency in English in the debates concerning the political confrontation of ideas from each side.

- Demonstrate abilities of analysis and criticism in relation to the various political positions using the fluid of the L2.

- Resolve properly the tasks assigned by the correct use of the L2.

4.1.3. Delimitation of the standards to ensure the execution of the tasks:

Content Standards:

- The students will explain perspectives of various ethnic, religious, or political groups. 
- The students will identify how major leaders influenced the WWII.

- The students will differentiate between the Axis Powers and the Allied Powers.

- The students will analyze changes in power during WWII.

- The students will criticize and defend decisions made during WWII.

- The students will compare and contrast life during a specific historical era and life today.

- The students will evaluate the influence of propaganda during WWII.

- The students will articulate connections between aspects of WWII.

Process Standards:

- The students will be respectful to others while collaborating.

- The students will work productively while collaborating with others.

- The students locate nonfiction reference materials.

- The students will evaluate the relevancy of information found in nonfiction reference materials.

- The students will demonstrate communication skills when presenting information orally.

- The students will demonstrate communication skills when presenting information in written form.

\subsubsection{List of authentic tasks:}

- Research project: you will research the events that led to the beginning of WWII.

- Journal Entries: write four journal entries reflecting on happenings from the WWII.

- Discussion: working with a partner, prepare to debate with another pair. You and your partner will be assigned to either criticize or defend topics from WWII.

- World War II Newspaper: create the front page of a newspaper written from a European perspective about the WWII.

- Concept Map: create a detailed concept map of WWII.

- Expository essay: in an expository essay, discuss the similarities and differences of life during WWII and today.

- Evaluating propaganda: using primary resources look at eleven piece of propaganda from WWII.

- Creating propaganda: after evaluating propaganda from the WWII, chose a message you think should have been send to an audience during that time period.

- Mock Interview: you are going to complete a mock interview with a major leader during the WWII.

\subsubsection{Developing some of the tasks:}

Research Project:

Standards:

- The students will identify how major leaders influenced the WWII. 
- The students will differentiate between the Axis Powers and the Allied Powers.

- The students will analyze changes in power during WWII.

- The students will locate information reference materials.

- The students will evaluate the relevancy of information found in nonfiction reference materials.

Description of the task:

Relevant nonfiction reference materials available include World Encyclopaedias, computerbased encyclopaedias, and websites. Depending on the event you are describing, you may or may not be able to include information in each area.

\section{RESEARCH RUBRIC}

\begin{tabular}{|l|l|l|l|}
\hline \multicolumn{1}{|c|}{ CRITERIA } & \multicolumn{1}{|c|}{$\mathbf{0}$} & \multicolumn{1}{c|}{$\mathbf{3}$} & \multicolumn{1}{c|}{$\mathbf{5}$} \\
\hline $\begin{array}{l}\text { Uses appropriate } \\
\text { nonfiction reference } \\
\text { materials }\end{array}$ & $\begin{array}{l}\text { Does not use any } \\
\text { appropriate nonfic- } \\
\text { tion } \\
\text { reference materials }\end{array}$ & $\begin{array}{l}\text { Uses some appropri- } \\
\text { ate } \\
\text { nonfiction reference } \\
\text { materials }\end{array}$ & $\begin{array}{l}\text { Uses all appropriate } \\
\text { nonfiction reference } \\
\text { materials }\end{array}$ \\
\hline $\begin{array}{l}\text { Demonstrates ef- } \\
\text { ficient } \\
\text { note-taking }\end{array}$ & $\begin{array}{l}\text { Does not demon- } \\
\text { strate } \\
\text { efficient note-taking }\end{array}$ & $\begin{array}{l}\text { Somewhat demon- } \\
\text { strate } \\
\text { efficient note-taking }\end{array}$ & $\begin{array}{l}\text { Fully demonstrates } \\
\text { efficiency note- } \\
\text { taking }\end{array}$ \\
\hline $\begin{array}{l}\text { Determines essential } \\
\text { information from } \\
\text { resources }\end{array}$ & $\begin{array}{l}\text { Does not determine } \\
\text { essential information } \\
\text { from resources }\end{array}$ & $\begin{array}{l}\text { Somewhat deter- } \\
\text { mines } \\
\text { essential information } \\
\text { from resources }\end{array}$ & $\begin{array}{l}\text { Fully determines } \\
\text { essential information } \\
\text { from resources }\end{array}$ \\
\hline
\end{tabular}

Total: /15

Debate:

Standards:

- The students will explain perspectives of various ethnic, religious, or political groups.

- The students will criticize and defend decisions made during WWII.

- The students will be respectful to others while collaborating.

- The students will work productively while collaborating with others.

- The students will demonstrate effective communication skills when presenting oral information.

Description of the task: Topics include the attack on Pearl Harbour, the dropping of the atomic bombs, the concentration camps, and the Japanese-American internment camps. For this assignment, you will be expected to reserve your personal feelings and opinions. 


\section{RUBRIC}

\begin{tabular}{|l|c|c|c|c|c|}
\hline \multicolumn{1}{|c|}{ CRITERIA } & POOR & FAIR & GOOD & VERY GOOD & EXCELLENT \\
\hline $\begin{array}{l}\text { PARTNERS WORK } \\
\text { WELL TOGETHER }\end{array}$ & 1 & 2 & 3 & 4 & 5 \\
\hline $\begin{array}{l}\text { PARTNERS SHARE } \\
\text { RESPONSIBILITIES }\end{array}$ & 1 & 2 & 3 & 4 & 5 \\
\hline $\begin{array}{l}\text { PARTNERS } \\
\text { EFFECTIVELY } \\
\text { CRITICIZE OR } \\
\text { DEFEND TOPICS }\end{array}$ & 1 & 4 & 7 & 8 & 10 \\
\hline $\begin{array}{l}\text { PARTNERS } \\
\text { EFFECTIVELY } \\
\text { DEBATE THE } \\
\text { OTHER PAIR }\end{array}$ & 1 & 4 & 7 & 8 & 10 \\
\hline $\begin{array}{l}\text { PARTNERS } \\
\text { RESERVE PERSONAL } \\
\text { OPINION FROM } \\
\text { TOPIC TO } \\
\text { EFFECTIVELY } \\
\begin{array}{l}\text { EXPLAIN THE } \\
\text { PERSPECTIVE } \\
\text { ASSIGNED }\end{array}\end{array}$ & 1 & 4 & 7 & 8 & \\
\hline
\end{tabular}

Total: $/ 40$

\section{Conclusions}

Throughout this exposition we have shown that an alternative evaluation of the learning outcomes in bilingual education is possible. Thanks to the authenticity of this new model,we can assess more accurately what the student is able to do, relegating additional evaluations and comparisons of results to a second level. What we find particularly interesting is that the evaluation is part of the process of teaching and learning, and is not perceived as an isolated event. This new conception of evaluation puts the students in the position as protagonists, and makes them responsible for the self-regulation of their learning process.

Authentic assessmentis a transparent procedure, and when we implement it, we can measure progress and levels of success of bilingual pupils in the use of the L2 to solve authentic tasks. When we make use of it in our bilingual classrooms, this new evaluative approach facilitates and encourages the language learning of our students, which already are conditioned by the pressure of examinations. They have a new stimulus to learn, because they no longer compete with anyone, but instead strive to maximize their own capacities. Everyone progresses and this progress depends on the effort they put into it. With the implementation of this model in our classrooms, we realize that our students reflect on their learning, self-evaluate themselves, learn from their mistakes, agree with the teacher's levels of demand and are more critical about the way they are taught. 
Ultimately, the continued practice of authentic assessment allows our students to perceive with clarity the usefulness of what they learn, helps them to appreciate the advantages of working on an ongoing basis and makes them take an active part in their own learning, stimuli to learn that in some ways are missing in the traditional assessment model.

\section{REFERENCES}

Ahumada, A. P. (2005). "La evaluación auténtica: un sistema para la obtención de evidencias y vivencias", en Perspectiva Educacional, 45: 11-24.

Antúnez, S., Carmen, L. M., Imbernon, F., Parecerisa, A. and Zabala, Z. (1997). Del proyecto educativo a la programación de aula. Barcelona: Graó.

Álvarez Valdivia, I. M. (2005). "Evaluación como situación de aprendizaje: evaluación auténtica", en Perspectiva Educacional, 35: 45-67.

Barberà Gregori, E. (1999). Evaluación de la enseñanza, evaluación del aprendizaje. Barcelona: Edebé.

Black, P. S and William, D. (1998). "Assessment and classroom learning", in Assessment in Education: Principles, policing and perspectives", 5, 1: 7-74.

Brown, H. D. (2004). Language Assessment: Principles and classroom practice. New York: Pearson Education.

Coelho E. (2004). Adding English: a guide to teaching in multilingual classroom. Toronto: Pippin Publishing Corporation.

Consejería de Educación, (2005). Plan de Fomento del Plurilingüismo en Andalucía. Sevilla: Junta de Andalucía.

Council of Europe (2001).Common European Framework of Reference for Languages: Learning, Teaching and Assessment. Cambridge: Cambridge University Press.

Chickering, A. W. and Gamson, Z. F. (1987). "Seven principles for Good Practice in the undergraduate Education", in AAHE Bulletin, 39: 3-7.

Cummins, J. (1978). "Metalinguistic development of children in bilingual education programs: data from Irish and Canadian Ukrainian-English programs", in Paradis, M. (ed.). Columbia: S. C. Hornbeam, 127-138.

Dobson, A., Pérez Murillo, M. D. y Johnstone, R. (2010). Programa de Educación Bilingüe en España: Informe de Evaluación. Madrid: MEC-British Council.

Duverger, J and Maillard, J. P. (1996). L'enseignement bilingue aujourd'hui. Bibliotheque Richandean: Albin Michel.

Gips, C. (1994). Beyond testing: towards a theory of educational assessment. London: Falmer Press.

Gulikers, J. T., Bastiaen, M. T. S. and Martens, R. (2005). "The superplus value of and authentic learning environment", in Computer in Human Behaviour, 21, 3: 509-531.

Gulikers, J. T., Bastiaens, M. T. S. and Kirshner, P. A. (2004). "A five-dimensional framework for authentic assessment", in Educational Technology Research and Development, 54, 3: 67-86.

López Alexis, A. (2005). "La evaluación formativa en la enseñanza del inglés", en $R$. Latinoamericana de Educación, Vol. 1, 3: 111-124.

Lorenzo F., Casal, S., Moore, P. and Alonso Y. (2009). "Bilingüismo y Educación: situación de la Red de Centros Bilingües en Andalucía”, en Actualidad, 39: 1-24. 
Lorenzo F., Trujillo, F. and Vez, J. M. (2004). Educación bilingüe: integración de contenidos y segundas lenguas. Madrid: Síntesis.

Margalef García, L. (2009). "Aprender a evaluar: transformar nuestras prácticas universitarias", en M. Castelló, (ed.). La evaluación auténtica en la enseñanza secundaria y universitaria: investigación e Innovación. Barcelona: Edebé, 15-28.

Marchese, T. J. (2001). "TQM reaches the academy", in AAHE Bulletin, 49: 3-9.

McDonald, J. P. (1992). "Dilemmas of planning backwards; rescuing a good idea", in Teachers College Record, 94: 152-169.

Mueller, J. (2005). "The authentic assessment toolbox: Enhancing student learning trough on line Faculty Development", in Journal on line learning and teaching, 1:13-35.

Pellicer Iborra, C. and Ortega Delgado, M. (2009). La evaluación de las competencias básicas: propuesta para evaluar el aprendizaje. Madrid: PPC.

Sánchez, M. P. and Tembleque, R. (1986). "La educación bilingüe y el aprendizaje de segundas lenguas: sus características y principios fundamentales", en Infancia y Aprendizaje, 33: 3-26.

Saddler, R. (1989). "Formative assessment in the design of instructional systems", in Instructional Science, 18: 119-144.

Stiggins, R. J. (1987). "The design and development of performance assessment”, in Educational Measures; issues and practice, 6: 33-42.

Stein, S. J., Isaac, S.G. and Andrews, T. (2004). "Incorporating authentic learning Experiences within a University course", in Studies in Higher Education, 29: 239-258.

Tudor, I. (2001). The Dynamics of language classroom. Cambridge: Cambridge University Press.

Wiggins, G. (1923). Assessing student Performance, San Francisco: Jossey. Vol. 1 Bass Publishers.

Wolf, D. P. (1993). “Assessment as an episode of learning”, in R. E. Bennet and W. Ward, (eds.). Construction versus choice in cognitive measurement. Hilldole, N. G. Laurence Erlbaum, 213-240.

Worthen, B. R and Sanders, J. M. (1973). Educational evaluation: theory and practice. Worthington, Ohio: C. A. Jones Publishing, Co. 